\title{
THE IMPACT OF PROJECT-BASED DIGITAL STORYTELLING ON ENHANCING EFL ORACY SKILLS AND MOTIVATION OF SAUDI UNIVERSITY STUDENTS Khaled Elkotb Mahmoud Elshehawy
}

\begin{abstract}
This study investigated the impact of project-based subtitled digital storytelling on enhancing EFL oracy skills (listening and speaking) and motivation of EFL Saudi University students. Forty- level two students, majoring English language at the University College of Taymaa, Saudi Arabia, were assigned and randomly distributed into two equivalent groups: experimental and control. The study adopted the quasi- experimental design and the qualitative interpretation. The instruments were EFL oracy checklist, EFL oracy test, EFL motivation questionnaire, and team-peer evaluation digital storytelling scoring rubric. t-test for independent samples and the effect size technique were employed to measure the differences between the means of the two groups. The findings indicated that there were statistically significant differences in the mean scores of the pre/post EFL oracy test and pre/post administration of the motivation questionnaire in favor of the experimental group. Moreover, interpreting the data qualitatively, encouraged the participants of the treatment in improving their EFL oracy skills and enhancing their motivation. Thus, this research is recommended in other areas like reading and writing.
\end{abstract}

Key words: EFL oracy skills, EFL motivation, projects, digital storytelling, subtitles.

مخلــص:

بثثت الدراسة الحالية تأثير القصص الرقمية القائمة على الدشروع في تعزيز مهارات الثفاهية والدافعية في اللغة الإنجليزية

كلغة أجنبية لدى طلاب الجامعة السعوديين. اشتملت عينه الدراسة غلى أربعين طالبا، تخصص الكيلي اللغة الإنجليزية من طلاب الكلية

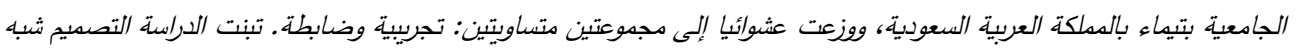

التجريبي بالإضافة إلى التغسير النوعي. تكونت أدوات الدراسة من: قائمه مرجعيه لدهارات الثناهية في اللغنة الانجليزية كلغة أجنبيه

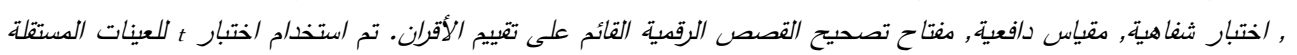

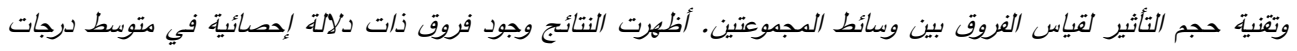

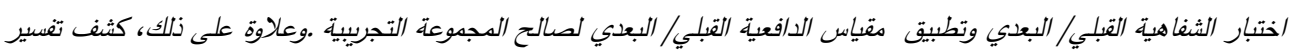

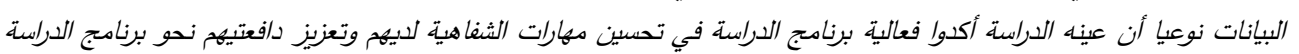

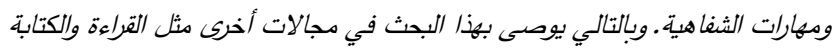

\section{Introduction}

Students often prefer instead of sitting in a class taking lessons to learning by doing, i.e. hands on tasks, which could be nourished for example, in project-based instruction. Moreover, they mostly get bored when they study in courses, but they do not when they watch movies or hear andlor tell stories. Why then EFL instructors do not allow learners to learn for example, through English subtitled movies and digital storytelling? If allowed, what would be the impact of these types of learning on the English language skills, particularly, listening and speaking (oracy skills)? Subsequently, the following question may be asked, what then would motivate students to learn English language especially, oracy skills? Hence, what is oracy?

The term oracy has been devised as a kind of parallelism for the term literacy in order to illustrate its importance in the process of teaching English language. Wilkinson, in his book Spoken English (Wilkinson, Davies and Atkinson, 1965) cited in Malherbe (1995, p.6) coined the term oracy. At that time, classroom work 
was dominated by reading and writing i.e. literacy. Consequently, many educationists felt the need to establish a parallel approach, encompassing listening and speaking and speaking skills are integrated.

Integration between the two main EFL oracy skills (listening and speaking) take several forms, as they are the core of acquiring communicative language competences (e.g. phonological knowledge, grammatical competence, pragmatic competence and sociolinguistic competence) in language learning. For example, the speaker needs the listener because speaking is rarely carried out in isolation as indicated by Redmond and Vrchota (2007, p.120) that, "speakers are at the mercy of listeners." Besides, the listening skill involves a list of processes of perception, interpretation, evaluation, retaining, recalling and reaction to the speakers. Therefore, listening will not occur in isolation; in other words there must be a speech to listen to.

In the field of TEFL, teaching listening and speaking for English language learners is quite complicated and it needs good educational instruments. Graham (2006) contends that students often complain that listening and speaking are their susceptible spots. This is because mastering these two skills is not easy, especially, for those living in countries where English is not their first language. Therefore, students are always looking for good educational tools to help them improve their EFL oracy skills and arouse their motivation while learning. Projectbased instruction approach is one of these educational tools as stated by many researches (e.g. Brinton, 2003; Brown, 2001; Eyring, 2001) .

There are a number of definitions for project-based instruction (PBI) and all of them clarify its importance in the educational process. For example, it is an authentic learning model or strategy in which students plan, implement, and evaluate projects that have real-world applications beyond the classroom (Blank, 1997; Westwood, 2008). Moreover, PBI has a number of merits in teaching English as a foreign or second language. For example, some researchers (e.g. Candlin, et al.,1988; Haas, 2000) claim that PBI is beneficial for L2 (EFL/ESL) education as it provides the learners with the chance to improve their accuracy, fluency, communicative competence and abilities in the target language by interacting and communicating with one another and with native speakers in real contexts.

Numerous studies highlighted from different perspectives the advantages of using PBI in the L2 (ESL/EFL) learning process. Some studies (e.g. Sarlak, 2016; Farouck, 2016) concentrated on the efficient role of PBI in developing the students' EFL speaking and communicative skills. In addition, other studies (e.g. Gardner, 1995) highlighted the impact of PBI in developing the students' listening skills. Furthermore, some of them (e.g. Kavlu, 2016) focused on one skill, reading skill or writing skill (e.g. Sadeghi, et al., 2016). Besides, others (e.g. Poonpon, 2008) dealt with the four skills all together. After this short review of the PBI approach literature, the question that arises here is what are the components of the projects of the current study?

In the current research, the proposed projects consisted of two of the most highly motivating educational instruments, namely, English language subtitles, particularly, the bimodal one and the digital storytelling. Subtitles are defined as the printed translation or the textual versions of the dialogue in films and television programs that one can read at the bottom of the screen when one is watching a foreign film (Canning-Wilson \& Wallace, 2000). Zanon (2006) cited in Rokni and Ataee (2014,p.716) distinguished three types of subtitling as 
follows: (1) Bimodal subtitling: From English dialogues to English subtitles and that type is followed in the present research; (2) Standard subtitling: From English dialogues to subtitles in the learners' mother tongue, and (3) Reversed subtitling: From dialogues in the learners' mother tongue to English subtitles.

Reviewing the previous studies that investigated the impact of using L2 subtitles in the field of L2 (ESL/EFL) instruction, revealed that various studies have been conducted to facilitate the acquisition of the four language skills either receptive (listening and reading) or productive (speaking and writing). For example, Rokni and Ataee (2014) examined the impact of subtitles on enhancing the learners' oral production skills. Moreover, Nasab and Motlagh (2017) highlighted the efficient role of subtitles in improving and increasing the learners' vocabulary recognition and comprehension. In addition, Wang (2014) demonstrated the significance of the subtitles in enhancing the learners' listening skills.

Concerning the second component of the PBI, digital storytelling (DS) can be considered a pedagogical instrument for L2 instructors to work on different areas of language in order to generate students' interest and motivation ( Masats, et al., 2009; Hottmann, et al., 2010). As indicated by Michalski, Hodges, and Banister (2005,p.2) that DST " involves telling stories using multimedia technologies, providing a format for students to put their thoughts together, visually, aurally, and kinesthetically ". Concerning the process of creating DS, Masats, et al. (2009) state that the learner can use software programs such as Camtasia Studio 8/7, iPhoto, iMovie, Power Point or Windows Movie Maker.

Several studies based on the benefits of DS in these educational environments have been conducted. These studies employed DS in the L2 (ESL/EFL) from different point of views. For example, Rokni and Qarajeh (2014) highlighted the importance of the DS in improving the oral skills of the L2 (ESL/EFL) learners. Furthermore, Tahriri (2015) demonstrated the positive impact of using DS on developing EFL oracy skills and motivation of the Iranain EFL students. Moreover, Xie (2016) demonstrated the influence of DS in improving the EFL motivation and efficiency in EFL learning of one of the EFL Chinese University students .

From the above discussion, it could be concluded that PBI approach with its two components-English subtitles and digital storytelling- settled in the present research are all motivating teaching approaches in the field of TEFL. Whereas EFL Saudi learners get bored so quickly, learning in motivating circumstances is very beneficial for them. Hence, it could be stated that the proposed program of this study is expected to be suitable for the nature of the EFL Saudi learners, particularly, the University students.

The data to show the problem of this study have been gathered from different sources:1)The pilot study which was conducted on the Saudi students: The oracy test and the motivation questionnaire, and 2) From the researcher's experience.

\section{Pilot Study}

To investigate the level of the oracy skills of the second level students at University College of Taymaa, University of Tabuk, Saudi Arabia, Department of Languages and Translation, a pilot study was conducted. A random sample of 20 students out of 40 students was selected to sit for an EFL oracy test. The test was based on the University students' textbook: New Head Way Plus-Pre Intermediate. It was designed by the researcher and validated by 6 EFL lecturers at the University of Tabuk. It consisted of ten- 
interview questions for each student to measure students' speaking skills using speaking checklist and a listening Table (1): Speaking Checklist Results

\begin{tabular}{|l|c|c|c|c|c|}
\hline \multicolumn{1}{|c|}{ Domain } & Poor & $\begin{array}{c}\text { Below } \\
\text { Average }\end{array}$ & $\begin{array}{c}\text { Very } \\
\text { Good }\end{array}$ & Excellent & $\begin{array}{c}\text { Students' } \\
\text { total number }\end{array}$ \\
\hline \multirow{2}{*}{ Fluency } & 10 & 5 & 5 & - & 20 \\
\cline { 2 - 5 } & $50 \%$ & $25 \%$ & $25 \%$ & $0 \%$ & \\
\hline Accuracy & 11 & 9 & - & - & 20 \\
\cline { 2 - 5 } & $55 \%$ & $45 \%$ & $0 \%$ & $0 \%$ & \multirow{2}{*}{20} \\
\cline { 2 - 5 } Vocabulary & 5 & 10 & 5 & & 20 \\
\hline \multirow{2}{*}{$\begin{array}{l}\text { Confidence \& Ability } \\
\text { to Communication }\end{array}$} & 8 & $50 \%$ & $25 \%$ & $0 \%$ & \multirow{2}{*}{$20 \%$} \\
\cline { 2 - 5 } & $40 \%$ & $35 \%$ & $25 \%$ & $0 \%$ & \\
\hline
\end{tabular}

The interpretation of table (1) shows the weakness of students in the speaking skills. Fluency: (10 students, poor, 50\%); (5 students, below average, 25\%); (5 students, very good, 25\%); (zero students, excellent, 0\%). Accuracy (11 students, poor, 55\%); (9 students, below average, $45 \%$ ); (zero students, very good, $0 \%$ ); (zero students, excellent, $0 \%$ ).

Vocabulary: (5 students, poor, 25\%); (10

Table (2): Students' Mean Score on the LCT

\begin{tabular}{|l|c|c|c|c|}
\hline \multicolumn{1}{|c|}{ Skills } & Total Scores & Mean & SD & (M) Ratio\% \\
\hline $\begin{array}{l}\text { Listening comprehension } \\
\text { Test ( LCT ) }\end{array}$ & 12 & 5.4 & 1.2 & $\% 64.8$ \\
\hline
\end{tabular}

Results in table (2) indicate that the mean score of the participants is 5.4 $(64.8 \%)$ which indicates that students need improvement in listening comprehension skills. The listening comprehension test total mark was 12 . Whereas 8 students obtained 4 marks (33\%). Moreover, 8 students obtained 6 marks $(50 \%)$ and 4 students obtained 7 marks $(58 \%)$. The interpretation of these results is a clear evidence on the students' poor level concerning EFL oracy skills.

Regarding students' motivation towards EFL oracy skills, through conducting an unstructured interview with the students (20 students), they stated different responses. As for the mistakes in speaking English, the students had a mix of reactions. Ten students affirmed that comprehension test to measure their listening comprehension. The results were as below: students, below average, 50\%); (5 students, very good, 25\%); (zero students, excellent, 0\%). Confidence and ability to communication ( 8 students, poor, $40 \%$ ); (7 students, below average, 35\%); (5 students, very good, 25\%); (zero students, excellent, 0\%). Concerning the listening skills, table (2) below illustrates the results.

they became very nervous when they tried to speak in English. Another group (7 students) of participants stated that their limited knowledge of English causes them to make mistakes. Moreover, 3 students expressed their dislike of speaking English and listening to tape scripts. As well as, 4 students agreed that they felt shy when speaking English. All students (20 students, $100 \%$ ) confirmed that lack of vocabulary, less exposure in real life English and less access to practice in English were the main causes of their mistakes in their spoken English.

In addition, the researcher's experience as a lecturer of English at the University of Tabuk, Taymaa Campus, Saudi Arabia for more than 4 years remarked the students' unsatisfactory 
performance in the EFL oracy skills. He also felt their unwillingness to participate in discussing in class due to their shyness and inability to talk fluently and/or accurately. Hence, he believed that implementing project-based subtitled digital stories treatment would reinforce the students' oracy skills and motivate them.

\section{Statement of the Problem}

Based on the results of the pilot study, the review of literature and the researcher's experience, the problem of the study is stated as follows: The EFL oracy skills and motivation of the Saudi University students need to be enhanced. Thus, this study investigated the impact of the project-based subtitled digital storytelling treatment on improving EFL oracy skills and motivation of the Saudi University students .

\section{Questions of the Study}

The present study answered the following main question:

What is the impact of project-based subtitled digital storytelling treatment on enhancing EFL oracy skills and motivation of Saudi University students?

The main question was answered by the following sub- questions:

1-What are the EFL oracy skills needed for the Saudi University students?

2-What is the impact of project-based subtitled digital storytelling treatment on enhancing the EFL listening skills for the Saudi University students?

3- What is the impact of project-based subtitled digital storytelling treatment on enhancing the EFL speaking skills for the Saudi University students?

4- What is the impact of project-based subtitled digital storytelling treatment on enhancing the EFL motivation of the Saudi University students?

\section{Purpose of the study}

The present study aimed at measuring the impact of project-based subtitled digital storytelling treatment on enhancing
EFL oracy skills and motivation of Saudi University students.

Significance of the Study

The present study is significant for a wide-range of audience as follows:

-Instructors: It is relevant to EFL tutors and teachers because implementing new pedagogical practices may result in effective outcomes for their students.

-Students: Implementing project-based subtitled digital storytelling treatment may provide a means for reviving students' interest and giving them opportunities to talk and make English more accessible and enjoyable. Thus, increased level of achievement over time may be obtained.

-Planners: It may assist researchers and raise the awareness of curriculum designers to plan new curricula making use of the proposed program of the present study for different levels and different disciplines.

\section{Delimitations of the Study}

The study was applied within the following delimitations:

1.The participants of the study included the students of the Department of Languages and Translation, Second Level, at the University of Tabuk, Taymaa Campus, only male students aged 18 to 23 .

2.The study was carried out in the second term of the academic year $2015 \backslash 2016$.

3.The study was restricted to the applied tools i.e. EFL oracy checklist, EFL oracy test, EFL motivation questionnaire and the Team-peer evaluation digital storytelling scoring rubric.

4.The study was conducted encompassing EFL oracy skills which are listening and speaking including their sub skills of the four language competences of phonological knowledge, grammatical competence, pragmatic competence and sociolinguistic competence in addition to the motivation variable. 
5.The study was conducted utilizing the project-based subtitled digital storytelling treatment.

\section{Hypotheses of the Study}

1- There is a statistically significant difference between the mean scores of the control group and that of the experimental group on the post administration of the EFL listening test in favor of the experimental group.

2-There is a statistically significant difference between the mean scores of the pre- and post-administration of the EFL listening test of the experimental group in favor of the post-test.

3-There is a statistically significant difference between the mean scores of the control group and that of the experimental group on the post administration of the EFL speaking test in favor of the experimental group.

4-There is a statistically significant difference between the mean scores of the pre- and post-application of the EFL speaking test of the experimental group in favor of the post-test.

5-There is a statistically significant difference between the mean scores of the control group and that of the experimental group on the post administration of the EFL motivation scale in favor of the experimental group.

6-There is a statistically significant difference between the mean scores of the pre- and post-application of the EFL motivation scale of the experimental group in favor of the post-test.

\section{Methodology of the Study}

\section{Participants of the Study}

From University College of Taymaa, Department of Languages and Translation, University of Tabuk, Saudi Arabia, 40 male students from the second academic level in the academic year 2015/2016, second term, were selected to be the participants of the study. Their ages were from 18 to 21 .

\section{Design of the Study}

The current study adopted the quasi experimental design. Two equivalent groups were formed, an experimental group (20 students) and a control one (20 students). The participants were randomly assigned to be either the experimental group or the control group. Furthermore, it included a qualitative interpretation to calculate the results and discuss the findings.

\section{Instruments of the Study}

The following instruments were designed and validated by the jurors to be used in the current research:

1. EFL Oracy Checklist: It worked as a guide for the study participants to identify the required oracy skills that they need to know and get familiar with. (Designed by the researcher)

2. EFL Oracy Test: It was designed by the researcher and aimed at measuring the impact of project-based subtitled digital stories intervention on the participants' achievement in their EFL oracy skills. (Designed by the researcher)

3. EFL Motivation Questionnaire : It was prepared to measure the impact of the project-based subtitled digital storytelling treatment on enhancing students' motivation towards EFL oracy skills and the subtitled digital storytelling projects. (Designed by the researcher)

4.Team-Peer Evaluation Digital Storytelling Scoring Rubric: It was prepared to assist the students of the experimental group to evaluate and get feedback on their subtitled digital storytelling products from their peers. (Designed by the researcher)

\section{Procedures of the study}

The literature and the previous studies related to EFL oracy skills, EFL motivation, project-based instruction 
approach, bimodal subtitles and digital storytelling were reviewed. The oracy lessons in the University of Tabuk EFL Course (New Headway Plus, PreIntermediate) and the required oracy skills according to the University course specification were identified.

Based on this review and the researcher's work experience (English language lecturer at University of Tabuk), an EFL oracy checklist was developed. It consisted of four language competences and their sub-skills (phonological knowledge, grammatical competence, pragmatic competence and sociolinguistic competence).These language competences represent the two main EFL oracy skills, namely, listening and speaking. Then, the jurors evaluated the oracy checklist content by deciding if they agree or disagree on the domains and their indicators. After validating, it worked as a guide for the study participants to identify the required oracy skills that they need to know and get familiar with throughout the program. Next, the bimodal subtitled videos needed for the treatment and the proposed program handout booklet were designed.

After that, the study instruments were designed. The content of the instruments was validated by 12 EFL Faculty teaching staff. Their feedback and recommendations were considered. Then, the reliability of the instruments was achieved through coefficient of Cronbach Alpha for internal consistency using the SPSS program. EFL oracy test reliability was found to be .821 and the EFL motivation questionnaire reliability was .814. Then, the pre-EFL oracy test and EFL motivation questionnaire were administered to both the experimental group and the control one in the first week of the second term of the academic year $2015 / 2016$ to identify the students' level of EFL oracy skills and their motivation towards EFL oracy skills and bimodal subtitled digital storytelling projects before the experiment.

Concerning the treatment, the experimental group students watched ten English bimodal subtitled videos based on the content of the University of Tabuk EFL textbook (New Headway Plus, PreIntermediate) themes. According to the themes of the University EFL textbook, some lectures had one bimodal subtitled video, other lectures had two videos. Each unit in the textbook contained one main oracy skills lesson with certain language competences (i.e. phonological knowledge, grammatical competence, pragmatic competence and sociolinguistic competence) under the title of " Listening and Speaking". The duration of the videos was the same duration of the tape scripts in the text book oracy skills lesson.

There were ten sessions in ten weeks, one session per week, which was the same number of sessions and weeks of the University traditional textbook. Each session continued for two hours which was the same time of the University traditional lecture. In each session students were divided into four teams. After watching the subtitled videos, students were asked to create subtitled digital stories based on the content of the videos. They obtained feedback from their peers and the researcher using the team-peer evaluation digital storytelling scoring rubric. They were also asked to create subtitled digital stories as homework assignments to be evaluated before the beginning of the new session. Teams' products were kept for evaluation and rewarding the winner team by the lecturer when presenting the Theatre Day at the end of the experiment.

At the end of the second term, the post-EFL oracy test and the postapplication of the EFL motivation questionnaire were administered to both groups to reveal the difference in the students' EFL oracy skills and in their motivation towards EFL oracy skills and 
bimodal subtitled digital storytelling projects, consequently measuring the impact of the proposed project-based bimodal subtitled digital stories treatment in enhancing their EFL oracy skills and motivation. Data were collected and analyzed quantitatively and qualitatively.

\section{Results and Discussion}

Testing the main hypothesis, the first hypothesis and the third hypothesis

Table (3): Results of the T-Test of the EG and CG on the Post-EOT

\begin{tabular}{|c|c|c|c|c|c|c|c|}
\hline Group & N & Mean & Std. Deviation & df & $\boldsymbol{t}$-Value & Sig. value & $\boldsymbol{P}$ \\
\hline Experimental & 20 & 31.40 & 3.761 & 38 & 9.468 & 0.000 & 0.01 \\
\hline Control & 20 & 21.15 & 3.048 & & & & \\
\hline
\end{tabular}

Results depicted in table (3) report the means and standard deviations of both EG and CG on the post EFL oracy skills (listening and speaking) test. The mean score of the EG was (31.40) with a standard deviation of (3.761), the mean score of the CG was (21.15) with a standard deviation of (3.048). This means that the statistical significant between the two groups is in favor of the experimental group. This is obvious as the $t$ value $(9.468)$ is statistically significant at the level (.01) favoring the EG. This means that the EG has significantly achieved a higher level of

Table (4): $t-$ Value of the EG and the CG over Listening and Speaking Sub-Skills on the Post EFL Oracy Test

\begin{tabular}{|c|c|c|c|c|c|c|c|c|}
\hline \multicolumn{9}{|c|}{ Post EFL Oracy } \\
\hline Listening \& Speaking Sub-Skills & Group & $\mathbf{N}$ & $\mathbf{M}$ & S.D. & df & t. Value & Sig. Value & $\boldsymbol{P}$ \\
\hline \multirow[t]{2}{*}{ Phonological Knowledge } & EG & 20 & 5.65 & .489 & 38 & & & \\
\hline & CG & 20 & 4.55 & .826 & & 5.126 & 0.000 & 0.01 \\
\hline \multirow[t]{2}{*}{ Grammatical Competence } & $\mathrm{EG}$ & 20 & 3.85 & .875 & & & & \\
\hline & CG & 20 & 2.50 & .889 & 38 & 4.841 & 0.000 & 0.01 \\
\hline \multirow[t]{2}{*}{ Pragmatic Competence } & EG & 20 & 3.15 & .813 & & & & \\
\hline & $\mathrm{CG}$ & 20 & 2.05 & .394 & 38 & 5.447 & 0.000 & 0.01 \\
\hline \multirow[t]{2}{*}{ Sociolinguistic Competence } & EG & 20 & 2.80 & .696 & & & & \\
\hline & $\mathrm{CG}$ & 20 & 1.75 & .550 & 38 & 5.294 & 0.000 & 0.01 \\
\hline \multirow[t]{2}{*}{ Fluency } & EG & 20 & 3.00 & .649 & & & & \\
\hline & $\mathrm{CG}$ & 20 & 1.80 & .410 & 38 & 6.990 & 0.000 & 0.01 \\
\hline \multirow[t]{2}{*}{ Accuracy } & EG & 20 & 3.15 & .671 & & & & \\
\hline & $\mathrm{CG}$ & 20 & 1.80 & .616 & 38 & 6.631 & 0.000 & 0.01 \\
\hline \multirow[t]{2}{*}{ Active Listening } & EG & 20 & 3.15 & .489 & & & & \\
\hline & $\mathrm{CG}$ & 20 & 2.10 & .641 & 38 & 5.824 & 0.000 & 0.01 \\
\hline \multirow{2}{*}{$\begin{array}{l}\text { Responding and } \\
\text { Comprehension }\end{array}$} & $\mathrm{EG}$ & 20 & 3.30 & .657 & & & & \\
\hline & CG & 20 & 2.00 & .649 & 38 & 6.296 & 0.000 & 0.01 \\
\hline \multirow{2}{*}{$\begin{array}{l}\text { Confidence and Performance } \\
\text { Skills }\end{array}$} & $\mathrm{EG}$ & 20 & 3.40 & .598 & & & & \\
\hline & $\mathrm{CG}$ & 20 & 2.10 & .553 & 38 & 7.139 & 0.000 & 0.01 \\
\hline
\end{tabular}

experimental group (EG) and the control group (CG) post-level of their EFL oracy skills after studying the proposed program (Project-based subtitled digital stories), a ttest for independent samples was used to determine any difference between the two groups' mean scores on the post-test. These findings are presented in table (3).

EFL oracy skills than the CG after applying the treatment. Thus, the main research hypothesis for this study which is: There is a statistically significant difference between the mean score of the EG and that of the CG on the post-EFL oracy skills at level (.01) favoring the EG is verified and accepted.

To be more precise, the researcher used the t-test for independent samples to calculate the $(\mathrm{t})$ value for each skill of the EFL oracy skills (listening and speaking) for the EG and the CG after the treatment. This is evident in table (4). 
It is seen in table (4) that the $(t)$ value $(5.126,4.841,5.447,5.294,6.990$ ,6.631, 5.824, 6.296,7.139) in each listening and speaking sub-skill respectively is statistically significant at the level (0.01) favoring the EG. In other terms, the EG outperformed the CG in their achievement in each listening and speaking sub-skill after the treatment. The significant differences between the EG and the CG sustain the effectiveness of the project-based subtitled digital stories on improving students' listening and speaking sub-skills in favor of the experimental group. Hence, the first and the third hypotheses of the study are verified.

To calculate the effect size of the project-based subtitled digital stories on the students' achievement level through the post EFL oracy test application of the experimental group and the control group, the researcher calculated the values of Eta square " $\eta 2$ " and Cohen's "d" as indicated in table (5).

Table (5) : "T" Value, Eta Square " $\eta 2$ " and Cohen's" d" for Each EOT Domain of the Post Test of the EG and CG and the Effect Size of the Treatment

\begin{tabular}{|l|l|l|l|l|l|}
\hline $\begin{array}{c}\text { Independent } \\
\text { Variable }\end{array}$ & \multicolumn{1}{|c|}{$\begin{array}{c}\text { EFL Oracy Test } \\
\text { Domains }\end{array}$} & T. Value & $\boldsymbol{\eta} 2$ & D & $\begin{array}{c}\text { Effect } \\
\text { Size }\end{array}$ \\
\hline & Phonological Knowledge & 5.126 & .409 & 1.620 & Large \\
\hline & $\begin{array}{l}\text { Grammatical } \\
\text { Competence }\end{array}$ & 4.841 & .381 & 1.530 & Large \\
\hline & Pragmatic Competence & 5.447 & .438 & 1.721 & Large \\
\hline $\begin{array}{l}\text { Project-based } \\
\text { Subtitled } \\
\text { Digital Stories }\end{array}$ & Competence & 5.294 & .424 & 1.673 & Large \\
\hline & Total of Part 1 & 8.649 & .663 & 2.734 & Large \\
\hline & Fluency & 6.990 & .562 & 2.210 & Large \\
\hline & Accuracy & 6.631 & .536 & 2.095 & Large \\
\hline & Active Listening & 5.824 & .472 & 1.841 & Large \\
\hline & $\begin{array}{l}\text { Responding and } \\
\text { Comprehension }\end{array}$ & 6.296 & .511 & 1.990 & Large \\
\hline & $\begin{array}{l}\text { Confidence and } \\
\text { Performance skills }\end{array}$ & 7.139 & .573 & 2.257 & Large \\
\hline & Total of Part 11 & 9.085 & .685 & 2.872 & Large \\
\hline & Total of Oracy Test & 9.468. & .702 & 2.994 & Large \\
\hline
\end{tabular}

Table (5) illustrates and reflects the large effect size of the project-based subtitled digital stories treatment on each of the EFL oracy skills and the total degree of the test of the experimental group students. In other words, the project-based subtitled digital stories treatment had a large effect in improving the EFL oracy skills (listening and speaking sub-skills) of the experimental group. Consequently, this confirms the acceptance and the verification of the main hypothesis, the first hypothesis and the third hypothesis.

\section{Testing the Second and Fourth Hypotheses}

To indicate the significance level of the difference in the mean scores of the EG in the pre-and post- test of the EFL oracy test, a t-test for independent variables was used. Table (6) shows the results: 
Table ( 6 ): Results of T-Test of EG on the Pre-Post Administration of the EFL Oracy Test

\begin{tabular}{|l|l|l|l|l|l|l|l|l|}
\hline Group & Applied & N & Mean & S.D. & df & t. Value & Sig. Value & $\boldsymbol{P}$ \\
\hline Experimental & Pre & 20 & 17.25 & 3.754 & & & & \multirow{2}{*}{0.01} \\
\cline { 2 - 10 } & Post & 20 & 31.40 & 3.761 & 38 & -11.908 & 0.000 & 0.01 \\
\hline
\end{tabular}

The result of the t-test demonstrates that the estimated t-value (11.908) is significant at (0.01) level. This means that there is a statistically significant difference at (0.01) level with $\mathrm{df}=(38)$ between the mean scores of the experimental group students on the pre and post-application of the EFL oracy test in favor of the post one. This means that the project-based subtitled

digital stories treatment was effective in developing EFL Saudi University students' EFL oracy skills.

To be more accurate, t-value is estimated for every EFL oracy skills (listening and speaking sub-skills) for the experimental group before and after the treatment. Table (7) demonstrates the findings.

Table (7): $t$-Value of the EG over Listening and Speaking Sub-Skills on the Pre- and PostEFL Oracy Test

\begin{tabular}{|c|c|c|c|c|c|c|c|c|}
\hline $\begin{array}{c}\text { Listening and Speaking } \\
\text { Sub-Skills }\end{array}$ & EG & $\mathbf{N}$ & Mean & S.D. & df & t-Value & $\begin{array}{c}\text { Sig. } \\
\text { Value }\end{array}$ & $\boldsymbol{P}$ \\
\hline \multirow{2}{*}{$\begin{array}{l}\text { Phonological } \\
\text { Knowledge }\end{array}$} & Pre & 20 & 4.70 & .979 & & & & \\
\hline & Post & 20 & 5.65 & .489 & 38 & 3.883 & 0.000 & 0.01 \\
\hline \multirow{2}{*}{$\begin{array}{l}\text { Grammatical } \\
\text { Competence }\end{array}$} & Pre & 20 & 2.25 & 1.164 & & & & \\
\hline & Post & 20 & 3.85 & .875 & 38 & 4.913 & 0.000 & 0.01 \\
\hline \multirow[t]{2}{*}{ Pragmatic Competence } & Pre & 20 & 1.25 & .550 & & & & \\
\hline & Post & 20 & 3.15 & .813 & 38 & 8.658 & 0.000 & 0.01 \\
\hline \multirow{2}{*}{$\begin{array}{l}\text { Sociolinguistic } \\
\text { Competence }\end{array}$} & Pre & 20 & 1.25 & .550 & & & & \\
\hline & Post & 20 & 2.80 & .696 & 38 & 7.815 & 0.000 & 0.01 \\
\hline \multirow[t]{2}{*}{ Fluency } & Pre & 20 & 1.50 & .513 & & & & \\
\hline & Post & 20 & 3.00 & .649 & 38 & 8.8110 & 0.000 & 0.01 \\
\hline \multirow[t]{2}{*}{ Accuracy } & Pre & 20 & 1.50 & .688 & & & & \\
\hline & Post & 20 & 3.15 & .671 & 38 & 7.678 & 0.000 & 0.01 \\
\hline \multirow[t]{2}{*}{ Active Listening } & Pre & 20 & 1.80 & .616 & & & & \\
\hline & Post & 20 & 3.15 & .489 & 38 & 7.677 & 0.000 & 0.01 \\
\hline \multirow{2}{*}{$\begin{array}{l}\text { Responding and } \\
\text { Comprehension }\end{array}$} & Pre & 20 & 1.65 & .671 & & & & \\
\hline & Post & 20 & 3.30 & .657 & 38 & 7.859 & 0.000 & 0.01 \\
\hline \multirow{2}{*}{$\begin{array}{l}\text { Confidence and } \\
\text { Performance Skills }\end{array}$} & Pre & 20 & 1.70 & .657 & & & & \\
\hline & Post & 20 & 3.40 & .598 & 38 & 8.556 & 0.000 & 0.01 \\
\hline
\end{tabular}

Results from table (7) illustrate that the estimated t-value $(3.883,4.913,8.658$, $7.815,8.8110,7.678,7.677,7.859,8.556)$ in each of the listening and speaking subskills respectively is significant at 0.01 level. This reflects the statistically significant differences between the mean scores of the pre-post administration in every listening and speaking sub-skill of the EFL oracy test of the experimental group in favor of the post-test. This means that using project-based subtitled digital stories treatment is very effective in improving the experimental group students' EFL oracy skills (listening and speaking sub-skills). Hence, the second and the fourth hypotheses are verified.

To calculate the effect size of the project-based subtitled digital stories on the pre-posttest of the experimental group, the researcher used Eta square " $\eta 2$ " and Cohen's " $d$ ".Table (8) outlines the results. 
Table(8): Effect Size of Project-Based Subtitled Digital Stories in Pre-and the Post Test Application on the EG

\begin{tabular}{|l|l|l|c|c|c|}
\hline \multicolumn{1}{|c|}{$\begin{array}{c}\text { Independent } \\
\text { Variable }\end{array}$} & $\begin{array}{c}\text { EFL Oracy Test } \\
\text { Domains }\end{array}$ & t. Value & $\mathbf{\eta 2}$ & $\mathbf{D}$ & $\begin{array}{c}\text { Effect } \\
\text { Size }\end{array}$ \\
\hline & Phonological Knowledge & 3.883 & .284 & 1.227 & Large \\
\hline & $\begin{array}{l}\text { Grammatical } \\
\text { Competence }\end{array}$ & 4.913 & .388 & 1.553 & Large \\
\hline & Pragmatic Competence & 8.658 & .664 & 2.737 & Large \\
\hline & $\begin{array}{l}\text { Sociolinguistic } \\
\text { Competence }\end{array}$ & 7.815 & .616 & 2.471 & Large \\
\hline $\begin{array}{l}\text { Project-Based } \\
\text { Subtitled } \\
\text { Digital Stories }\end{array}$ & Total of part 1 & 10.509 & .744 & 3.323 & Large \\
\hline & Fluency & 8.110 & .634 & 2.564 & Large \\
\hline & Accuracy & 7.678 & .608 & 2.428 & Large \\
\hline & Active Listening & 7.671 & .608 & 2.427 & Large \\
\hline & $\begin{array}{l}\text { Responding and } \\
\text { Comprehension }\end{array}$ & 7.859 & .619 & 2.484 & Large \\
\hline & $\begin{array}{l}\text { Confidence and } \\
\text { performance skills }\end{array}$ & 8.556 & .658 & 2.706 & Large \\
\hline & Total of part 11 & 10.806 & .754 & 3.416 & Large \\
\hline & Total of Oracy Test & 11.908 & .789 & 3.765 & Large \\
\hline
\end{tabular}

Table (8) indicates that there is a large effect size of each item and the total degrees of the EFL oracy test. This means that the project-based subtitled digital stories treatment had a large effect and developed the EFL oracy skills (listening and speaking) of the experimental group. Hence, it could be guaranteed that the project-based subtitled digital storytelling approach had a significant effect on enhancing EFL Saudi University students' confirms the verification and acceptance of the second and the fourth hypotheses.

Testing the Fifth Hypothesis

The researcher used t-test for independent samples to determine the statistical significance level of the differences in the mean scores and standard deviations of the EG and the CG on the post-administration of the EFL motivation questionnaire (EMQ). Table (9) demonstrates the results. EFL oracy skills. Accordingly, this

Table (9): Total Average Score Differences Between EG and CG in the Post Application of

\begin{tabular}{|c|c|c|c|c|c|c|c|c|}
\hline Domain & Group & $\mathbf{N}$ & Mean & S.D. & Df & T.Value & Sig. value & $\mathbf{P}$ \\
\hline \multirow{2}{*}{$\begin{array}{l}\text { Motivation Towards } \\
\text { EFL Oracy skills } \\
\text { (Listening and } \\
\text { Speaking) }\end{array}$} & EG & 20 & 52.62 & 1.565 & \multirow[t]{2}{*}{38} & \multirow[t]{2}{*}{31.227} & \multirow[t]{2}{*}{0.000} & \multirow[t]{2}{*}{0.01} \\
\hline & CG & 20 & 31.55 & 2.585 & & & & \\
\hline \multirow{2}{*}{$\begin{array}{l}\text { Motivation Towards } \\
\text { Project-Based } \\
\text { Subtitled Digital } \\
\text { Stories }\end{array}$} & EG & 20 & 51.45 & 2.373 & \multirow[t]{2}{*}{38} & \multirow{2}{*}{$\begin{array}{l}30.293 \\
30.293\end{array}$} & \multirow{2}{*}{$\begin{array}{l}0.000 \\
0.000\end{array}$} & \multirow{2}{*}{$\begin{array}{l}0.01 \\
0.01\end{array}$} \\
\hline & CG & 20 & 51.45 & 2.373 & & & & \\
\hline \multirow{2}{*}{$\begin{array}{l}\text { Questionnaire } \\
\text { Total Degree }\end{array}$} & EG & 20 & 104.10 & 3.684 & \multirow[t]{2}{*}{38} & \multirow[t]{2}{*}{33.919} & \multirow[t]{2}{*}{0.000} & \multirow[t]{2}{*}{0.01} \\
\hline & CG & 20 & 61.80 & 4.188 & & & & \\
\hline
\end{tabular}


Table (9) indicates the (t) computed value, (33.919), and the significant differences at the level (0.01) between the experimental group and the control one concerning the total degree of the EFL motivation questionnaire in favor of the experimental group. In addition, there are significant differences between the means of the EG (104.10) and the CG (61.80) in favor of the experimental group. There are also significant differences between the standard deviations of the EG (3.684) and the CG (4.188) in favor of the experimental group. These results confirm

Table (10): Effect Size of the EG and CG Post Application of the EMQ Domains and Total Score

\begin{tabular}{|l|l|c|c|c|c|}
\hline \multicolumn{1}{|c|}{$\begin{array}{c}\text { Independent } \\
\text { Variable }\end{array}$} & \multicolumn{1}{|c|}{ Domains of EMQ } & $\begin{array}{c}\text { T. } \\
\text { Value }\end{array}$ & $\boldsymbol{\eta} 2$ & D & $\begin{array}{c}\text { Effect } \\
\text { Size }\end{array}$ \\
\hline & $\begin{array}{l}\text { Motivation Towards EFL } \\
\text { Oracy Skills (Listening } \\
\text { and Speaking ) }\end{array}$ & 31.227 & 0.962 & 9.860 & Large \\
\hline $\begin{array}{l}\text { Project-Based } \\
\text { Subtitled Digital } \\
\text { Stories }\end{array}$ & $\begin{array}{l}\text { Motivation Towards } \\
\text { Project- Based Subtitled } \\
\text { Digital Stories Treatment. }\end{array}$ & 30.293 & 0.960 & 9.578 & Large \\
\hline & $\begin{array}{l}\text { Total Degree of the } \\
\text { Questionnaire }\end{array}$ & 33.919 & 0.968 & $\begin{array}{l}10.70 \\
7\end{array}$ & Large \\
\hline
\end{tabular}

Saudi University students' motivation towards EFL oracy skills as follows: " $\mathrm{t}$ " value was ( 31.227$)$," $\eta 2$ " equaled (0.962) and " $d$ " equaled (9.860). This means that the project-based subtitled digital stories treatment had a large effect on enhancing students' motivation towards EFL oracy skills. In addition, the table illustrates the results of the students' motivation towards the effectiveness of project-based subtitled digital stories treatment as follows: " $\mathrm{t}$ " value was ( $30.293), " \eta 2$ " equaled (0.960) and " $\mathrm{d}$ " equaled (9.578).This means that projectbased subtitled digital stories treatment had a large effect as students' motivation enhanced towards it.

Besides, table (10) indicates the results of the total degree of the questionnaire as follows :"t" value the effectiveness of the project-based subtitled digital stories treatment on enhancing the EFL Saudi University students' motivation towards EFL oracy skills and project-based subtitled digital stories treatment. Consequently, the fifth hypothesis of the study is verified and accepted.

To calculate the effect size of each domain and the total score of the EG and CG post application of the EFL motivation questionnaire, the researcher used Eta square " $\eta 2$ " and Cohen's " d ". Table (10) demonstrates the results. 
Table (11): Total Average Score Differences Between EG Pre-Post Application of the EMQ

\begin{tabular}{|c|c|c|c|c|c|c|c|c|}
\hline Domain & EG & $\mathbf{N}$ & Mean & S.D. & df & t.Value & $\begin{array}{l}\text { Sig. } \\
\text { Value }\end{array}$ & $\mathbf{P}$ \\
\hline \multirow{2}{*}{$\begin{array}{l}\text { Motivation Towards } \\
\text { EFL Oracy Skills } \\
\text { (Listening and } \\
\text { Speaking) }\end{array}$} & Pre & 20 & 30.70 & 3.230 & \multirow[t]{2}{*}{38} & \multirow[t]{2}{*}{26.734} & \multirow[t]{2}{*}{0.000} & \multirow[t]{2}{*}{0.01} \\
\hline & Post & 20 & 52.60 & 1.729 & & & & \\
\hline \multirow{2}{*}{$\begin{array}{l}\text { Motivation Towards } \\
\text { Project- Based } \\
\text { Subtitled Digital } \\
\text { Stories Treatment. }\end{array}$} & Pre & 20 & 26.15 & 3.200 & 38 & 28.391 & 0.000 & 0.01 \\
\hline & Post & 20 & 51.60 & 2.415 & & & & \\
\hline \multirow{2}{*}{$\begin{array}{l}\text { Total Degree of } \\
\text { Questionnaire }\end{array}$} & Pre & 20 & 56.85 & 5.733 & \multirow[t]{2}{*}{38} & \multirow[t]{2}{*}{30.602} & \multirow[t]{2}{*}{0.000} & \multirow[t]{2}{*}{0.01} \\
\hline & Post & 20 & 104.20 & 3.874 & & & & \\
\hline
\end{tabular}

It is apparent from table (11) that the (t) computed value $(30.602)$ of the total degree of the questionnaire indicates that there are significant differences at $(0.01)$ between the experimental group students on the pre and post-applications of the EFL motivation questionnaire in favor of the post one. Moreover, there are significant differences between the means of both pre EG (56.85) and post EG (104.20) applications in favor of the EG post application. Furthermore, there are significant differences between the standard deviation of both pre EG (5.733) and post EG (3.874) applications in favor of the EG post application. These results assure the effectiveness of the projectbased subtitled digital stories treatment on developing the experimental group students' motivation towards EFL oracy skills and the project-based subtitled digital stories treatment. Thus, the sixth hypothesis of the study is accepted.

To calculate the effect size of each domain and the total score of the experimental group pre-and postapplication of the EFL motivation questionnaire, the researcher used Eta square " 2 " and Cohen's" d". Table (12) illustrates the results.

Table (12): Effect Size of the EG Pre-and Post- Application of the EMQ Domains and Total Score

\begin{tabular}{|c|c|c|c|c|c|}
\hline $\begin{array}{l}\text { Independent } \\
\text { Variable }\end{array}$ & Domains of EMQ & $\begin{array}{c}\text { T. } \\
\text { Value }\end{array}$ & $\eta 2$ & D & $\begin{array}{l}\text { Effect } \\
\text { Size }\end{array}$ \\
\hline \multirow{3}{*}{$\begin{array}{l}\text { Project-Based } \\
\text { Subtitled Digital } \\
\text { Stories }\end{array}$} & $\begin{array}{l}\text { Motivation Towards EFL } \\
\text { Oracy Skills (Listening and } \\
\text { Speaking) }\end{array}$ & 26.734 & 0.950 & 8.453 & Large \\
\hline & $\begin{array}{l}\text { Motivation Towards Project- } \\
\text { Based Subtitled Digital } \\
\text { Stories Treatment }\end{array}$ & 28.391 & 0.955 & 8.977 & Large \\
\hline & $\begin{array}{l}\text { Total Degree of the } \\
\text { Questionnaire }\end{array}$ & 30.602 & 0.961 & 9.677 & Large \\
\hline \multicolumn{6}{|c|}{$\begin{aligned} \text { Table (12) demonstrates the results } & \text { clear that " } \mathrm{t} \text { " values }((26.734),(28.391), \\
\text { of the effect size of the experimental group } & (30.602)), " \eta 2 " \text { values }((0.950),(0.955 \\
\text { pre-and post-application of the EMQ. It is } & ),(0.961)) \text { and " } \mathrm{d} \text { " values ( ( 8.453), }\end{aligned}$} \\
\hline
\end{tabular}


8.977), ( 9.677) ) of the three domains of the EMQ respectively indicate that the project-based subtitled digital stories treatment had a large effect on enhancing the experimental group students' motivation towards EFL oracy skills and project-based subtitled digital stories treatment. Consequently, this proves the verification and acceptance of the sixth research hypothesis as well.

Based on the results of t-test for independent samples and the effect size demonstrated in the above tables, the hypotheses of the study are statistically verified and accepted. Concerning the qualitative results of the study, they are interpreted, according to the experimental group students' comments on the statements of the EFL questionnaire motivation and how they benefited or not from the project-based subtitled digital stories treatment. The majority of the 20 participants of the experimental group students were motivated to conduct the project-based subtitled digital stories treatment, regardless of the very few problems the respondents expressed in their comments. Besides, all the participants reported that after the treatment, they felt improvement in their oracy skills. Consequently, their willingness and motivation during the treatment and after it increased. Furthermore, the clear and systematic procedures of the program as indicated by one of the participants contributed to sustaining the participants' feeling of success and to their awareness of the effectiveness of the good experience they were passing through in developing their EFL oracy skills.

\section{Conclusion}

According to the obtained results of the current study, it was concluded that the project-based subtitled digital stories treatment was effective for two reasons. The first reason, there was a correlation between the present study results and those of the previous studies. The second reason, the present study provided evidence on the effectiveness of using project-based subtitled digital storytelling treatment in enhancing EFL university students' EFL oracy skills and EFL motivation.

Concerning the first reason, the results of the present study are joined and added to the validity of other studies.The review of these previous studies made it clear that there is a research gap as there is a dearth in the studies that investigated the impact of project-based instruction approach, digital storytelling and bimodal subtitled videos on enhancing EFL oracy skills and EFL motivation. In addition, there are no studies that used the three instructing techniques together within the L2 (ESL/EFL) context. Based on these research gaps, the current research acquires its significance in the field of TEFL instruction as it fills these gaps by investigating the impact of project-based subtitled digital stories treatment on the EFL Saudi University students' EFL oracy skills and motivation .

Pertaining to the second reason, the results of the study provided strong evidence on the fruitfulness of the treatment in several forms. Firstly, the project-based subtitled digital stories treatment led to higher achievement in the participants' EFL oracy skills, particularly, the four language competences of phonological knowledge, grammatical competence, pragmatic competence and sociolinguistic competence. Besides, the treatment resulted in the enhancement of the participants' motivation towards EFL oracy skills and the project-based subtitled digital storytelling treatment.

Secondly, project-based subtitled digital stories treatment provided the respondents with a substantial opportunity to learn in an authentic and real situations life- like environment, to learn how to design, carry out, and evaluate a project that required sustained effort over a 
significant period of time. Additionally, this treatment raised the degree of competition among the teams of students (four teams). The teams entered into a friendly competition with other teams during creating their digital products and exerted effort to be the winning team on the Theatre Day.

Finally, this treatment enabled the participants to play several roles during the lectures such as thinkers, problem-solvers, leaders, spokespersons, and researchers. These roles assisted the participants to develop their EFL oracy skills as most of the discussions between the teams were in English. Moreover, it transferred instruction from " instructor telling" to "students doing". All these characteristics of the project-based subtitled digital stories treatment enabled the participants to acquire the $21^{\text {st }}$ Century skills such as collaboration with others ; hands onlearning or learning by doing; applying technology in learning; making decisions; taking initiatives and working autonomously to build their knowledge.

\section{Recommendations of the Study}

In light of the results and conclusion of the present study, the following recommendations are offered to the different parties interested in TEFL :

1- EFL instructors are recommended to cope with the modern trends in instructing EFL as they are prerequisites for the $21^{\text {st }}$ Century instruction .

2- Project-based subtitled digital stories treatment is strongly recommended for EFL instructors to instruct EFL oracy skills, particularly, the four language competences of phonological knowledge, grammatical competence, pragmatic competence and sociolinguistic competence. This is because it is very motivating instructing technique.

3- The choice of the subtitled digital storytelling projects should be appropriate to the students' needs and experiences to make the lecture atmosphere enjoyable, motivating and interesting.

4- The EFL curriculum should be enriched with these types of projects as they enhance the EFL students' use of English inside and outside the lecture room. Moreover, they expose them to authentic and real life situations when instructing EFL oracy skills and other language areas.

5-The subtitled digital storytelling projects instructing technique is recommended to be used as a medium of instruction in teaching reading and writing.

6- It is recommended to hold training courses to the EFL instructors to train them on how to use and evaluate the project-based instruction approach effectively within their EFL classes.

7- Peer evaluation and authentic assessment should be added to formative and summative ones within the TEFL context in the University of Tabuk and other educational settings.

8-The notion that creating projects within the EFL educational context is wasting-time activities on the part of some instructors and students should be discarded. As they should be aware of the merits of projects (e.g. cooperative learning, critical thinking, experiential learning, creativity, technological skills, making sense of learning, ....etc) which are very essential in teaching different areas of TEFL.

\section{Suggestions for Further Research}

Based on the study findings and its recommendations, the following research ideas can be considered for future research:

1- Future research could use the same treatment to develop other English language skills such as writing and reading , for EFL Saudi University students or others. 
2- It could be fruitful, if future research investigated the impact of the projectbased subtitled digital stories treatment on understanding the items and techniques of literary texts such as novel or drama for the students of Department of Languages and Translation with the University of Tabuk or elsewhere.

3- Future research could investigate the perceptions of EFL instructors at different educational stages (e.g. university level, secondary level............etc) concerning the application of the project-based subtitled digital stories treatment within their EFL classrooms.

4- Future research could focus on the effect of holding training project-based instruction courses to the EFL instructors at the different educational levels to increase their awareness on how to use and evaluate this instructing approach effectively within their EFL classes.

6- It could be useful for the educational process, if future research considered the impact of applying project-based instruction approach on acquiring the EFL students at the different educational levels the $21^{\text {st }}$ Century skills (e.g. cooperative learning, handson learning, reflective learning, technological skills, autonomous learning.............etc) .

7- It would be a good idea, if future research investigated the interdependence between EFL oracy skills and EFL literacy skills when using project-based subtitled digital storytelling treatment.

\section{References}

1. Blank, W. (1997). Authentic Instruction. Blank, W. E. and Harwell, S. (Eds.). Promising Practices for Connecting High School to the Real World. Tampa, FL: University of South Florida.
2. Brinton, D. (2003). Content-Based Instruction. In Practical English Language Teaching .ed. D. Nunan,199-224.New York: McGrawHill.

3. Brown, H. D. (2001). Teaching by Principles: An Interactive Approach to Language Pedagogy. White Plains,NY: Addison Wesley Longman, Inc.

4. Candlin, C., et al. (1988). Experiential Learning: Theory Into Practice. Paper Presented to the TESOL Colloquium, Chicago.

5. Canning-Wilson, C., \& Wallace, J. (2000). Practical Aspects of Using Video in the Foreign Language Classroom. The Internet TESL Journal, 6, 36-31.

6. Eyring, J. L. (2001). Experiential and Negotiated Language Learning. In Teaching English as A Second or Foreign Language. $3^{\text {rd }}$ ed.ed.M.CelceMurica,333-44.Boston.Heinle and Heinle.

7. Farouck, I. (2016). A Project-Based Language Learning Model for Improving the Willingness to Communicate of EFL Students. Proceedings of IMCIC - ICSIT 2016. Retrieved April 12,2017 www.iiis.org/CDs2016/CD20

8. Gardner, D.C. (1995). Student Produced Video Documentary Provides a Real Reason for Using the Target Language. Language Learning Journal, 12,54-56.

9. Graham, S. (2006). Listening Comprehension: The Learners' Perspective. System, 34, 165-182.

10.Haas, M .(2000). Thematic Communicative Language Teaching in the K-8 Classroom. EricDigest,EDOFL-00-04. Retrieved 20 October, 2016 from: http://www.usc.edu/dept/educa

11. Hottmann, A., et al. (2010). Video Production and Language Learning. Retrieved September 19, 2016 , from: https://is.muni.cz/th/273849/pedf b/ 
12. Kavlu, A. (2016). Enhancement of English as a Foreign Language (EFL) University Students' Reading Skills Through Project-Based Learning Implementation (Iraqi Case) . Doctoral Dissertation in Education Sciences. International Black Sea University, Tbilisi, Georgia

13. Masats, D., et al. (2009). Exploring the Potential of Language Learning Through Video Making. Proceedings of EDULEARN09 Conference: 341352. Moodle. Web. 2010. Retrieved August 11, 2016 from: https://www.researchgate.net/publicati on/

14. Michalski, P., et al. (2005). Digital Storytelling in the Middle Childhood Special Education Classroom: A Teacher's Story of Adaptations. Teaching Exceptional Children Plus, 1 (4) Article 3. Retrieved February 5 , 2017 from: http://escholarship.bc.edu/education/

15. Nasab, M.S.B. \& Motlagh, S. F. P. (2017) . Vocabulary Learning Promotion Through English Subtitled Cartoons. Communication and Linguistics Studies;3(1-1):1-7. Retrieved April 21, 2017 from : http://www.sciencepublishinggroup.co $\underline{\mathrm{m} / \mathrm{j} / \mathrm{cls}}$

16. Nazzal, M. J. (2102). A Study of Influence of English For Palestine Twelfth Grade Curriculum on Students' Communicative and Linguistic Proficiencies in Governmental Schools. PhD Thesis. Faculty of Education and Psychology. The Maharaja Sayajiro University of Baroda.

17. Poonpon, K. (2008). Enhancing English Skills Through Project-based Learning . The English Teacher Vol. XL: 1-10 . Retrieved Feb 7, 2016from: http://ednet.kku.ac.th/

18. Rokni, S. J. A. \& Ataee, A. J. (2014). The Effect of Movie Subtitles on EFL
Learners' Oral Performance. International Journal of English Language, Literature and Humanities. Vol. 1 .No.5.

19. Rokni, S.J.A \& Qarajeh , M. (2014). Digital Storytelling in EFL Classrooms: The Effect on the Oral Performance. International Journal of Language and Linguistics, 2(4). Retrieved October 5,2016 from: http://www.sciencepublishinggroup.co $\underline{\mathrm{m} / \mathrm{j} / \mathrm{ijll}}$

20. Sadeghi, H., et al. (2016). The Impact of Project-Based Language Learning on Iranian EFL Learner's Comparison/ Contrast Paragraph Writing Skills. International Journal of Asian Social Science, 2016, 6(9): 510-524

21. Sarlak, T. (2016).The Effect of Project Work on the Speaking Ability of Iranian EFL beginner Students Journal of Applied Linguistics and Language Research volume 3, issue, pp. 167-177. Retrieved April 23, 2017 from: www.jallr.com.

22. Tahriri, A. (2015). The Impact of Digital Storytelling on EFL Learners' Oracy Skills and Motivation. International Journal of Applied Linguistics \& English Literature Vol. 4 No. 3. Retrieved on April 13,2015 from : http://dx.doi.org/

23. Wang,Y. (2014). The Effects of L1/L2 Subtitled American TV Series on Chinese EFL Students' Listening Comprehension. Unpublished MA. Dissertation, Michigan State .

24. Westwood, P. (2008 ). What Teachers Need to Know About Teaching Methods. Camberwell, Victoria : ACER Press. Retrieved Jan 25, 2016 from : http://albaniarsimin.wikis

25. Xie, J. (2016). Digital Storytelling to Promote EFL Students' Motivation and Efficiency in Content-Based Classroom . Education Journal 5(6): 166-173.Retrieved April 10, 2017 from: 


$$
\begin{aligned}
& \text { http://www.sciencepublishinggroup.co } \\
& \underline{\mathrm{m} /} \\
& \text { المر اجع العربية }
\end{aligned}
$$

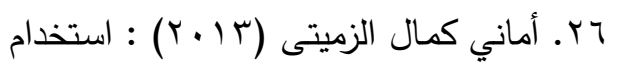

$$
\begin{aligned}
& \text { القصص المصسورة في تدريس التراكيب } \\
& \text { والقواعد اللغوية وأثرها في تتميه مهارات }
\end{aligned}
$$

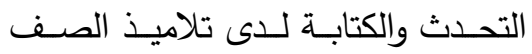

$$
\begin{aligned}
& \text { الرابع الابتدائي, أطروحة ماجستير , كليه } \\
& \text { التربية, جامعه بورسعيد. }
\end{aligned}
$$

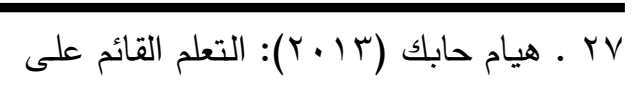

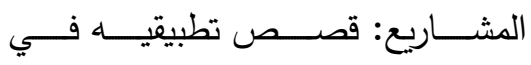

المؤسسات التعليمية.

Retrieved November.7,2016

from : http// blog.naseej.com

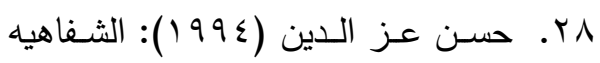

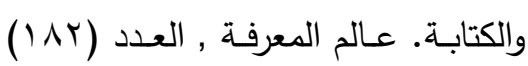

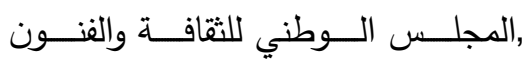

والآداب-الكويت. 